\title{
Effect of Cereal Monoculture and Tillage Systems on Grain Yield and Weed Infestation of Winter Durum Wheat
}

\author{
Andrzej Woźniak ${ }^{1}$ (1)
}

Received: 22 March 2019 / Accepted: 9 July 2019 / Published online: 12 July 2019

(c) The Author(s) 2019

\begin{abstract}
This experiment aimed at evaluating the yield and weed infestation of winter durum wheat grown in a multi-year cereal monoculture (CM) and crop rotation (CR) as well as in three tillage systems: (1) conventional tillage-CT, (2) reduced tillage-RT, and (3) no-tillage-NT. Shallow ploughing and pre-sowing ploughing were performed in the CT system; a cultivator and a cultivating set were used in the RT system, whereas glyphosate and a cultivating set were applied in the NT system. Grain yield was lower in CM than in CR $\left(1.43 \mathrm{tha}^{-1}\right.$ vs. $\left.3.91 \mathrm{t} \mathrm{ha}^{-1}\right)$ as well as in NT than in RT and CT systems. Grain yield and its components were determined to a greater extent by cropping systems (CS) than by tillage systems (TS). The number and air-dry weight of weeds per $\mathrm{m}^{2}$ were higher in CM than in CR, and also in RT than in NT and CT, and were found to be more affected by TS than by CS. At the tillering stage of wheat, more weed species occurred in CM than in CR, whereas at the stage of waxy maturity of wheat—in CR than in CM. Likewise, a higher number of weed species was identified in RT than in CT and NT systems.
\end{abstract}

Keywords Cropping systems $\cdot$ Tillage systems $\cdot$ Number of weeds $\cdot$ Air-dry weight of weeds $\cdot$ Species composition of weeds

\section{Introduction}

Crop rotations with legumes, root plants, and catch crops as well as soil cultivation with the use of mulch represent the basic elements of sustainable agriculture. Conditions of the crop rotation system ensure high and stable yields, and soil enrichment with organic carbon (Peigné et al. 2007; Montemurro 2009; Zikeli et al. 2013; Woźniak and Soroka 2018). Completely different conditions are offered by the monoculture, because it impoverishes both organic matter and microbiological life in the soil (Balota et al. 2004; Maillard et al. 2016), leads to increased weed infestation, and deteriorates the phytosanitary status of a stand (Hernández-Restrepo et al. 2016; Tillmann et al. 2017; Calzarano et al. 2018). All these negative outcomes result in grain yield decrease and grain quality deterioration (Woźniak and Stępniowska 2017). A research conducted by Woźniak and Soroka (2015) in a 24-year cereal monoculture has demonstrated a high increase

Andrzej Woźniak

andrzej.wozniak@up.lublin.pl

1 Department of Herbology and Plant Cultivation Techniques, University of Life Sciences in Lublin, Lublin, Poland in the number and biomass of weeds in the first years of the monoculture, followed by the stabilization of weed infestation in its successive years. The number and biomass of weeds were significantly lower in crop rotations than in the monoculture and depended on the previous crops, however the major weed species identified therein were typical of the root plants from the order Polygono-Chenopodietalia. As reported by Chauhan et al. (2012), crop cultivation in the monoculture leads to the prevalence of a few predominating weed species that are difficult to eradicate. In the research conducted by Woźniak and Soroka (2015), these were weed species typical of the Apero spica-venti-Papaveretum rhoeadis assembly. Also tillage system has been reported to have a strong influence on weed infestation in crop stands (Tuesca et al. 2001; Chauhan et al. 2006; Lahmar 2010). Generally, it may be stated that the no-tillage (NT) system used on moderately-humid fields increas weed infestation (Pekrun and Claupein 2006; Gruber et al. 2012; Woźniak 2018), whereas glyphosate use in this system results in effective weed eradication (Moyer et al. 1994; Hernández Plaza et al. 2015; Koning et al. 2019).

Increased weed infestation, deteriorated health status of plants, and adverse changes in the soil in the monoculture 
result in a decreased grain yield (Sieling et al. 2005; Pardo et al. 2008; Shahzad et al. 2016). Usually, grain yield reduction is due to a decrease in the value of one or a few yield components-spike number, grain weight per spike, 1000 grain weight, and grain number per spike (Woźniak and Soroka 2018). However, response of cereals to cultivation in the monoculture varies and is limited by habitat conditions, agrotechnical measures used, and many other factors. The yield of cereals is also affected by tillage systems (Gruber et al. 2012; Zikeli et al. 2013; Montemurro and Maiorana 2015). Many research works have demonstrated that better production results are achieved in the conventional tillage system on moderately humid soils as well as in the no-tillage system on dry soils or in the years with low sums of precipitation (López-Bellido et al. 1996; De Vita et al. 2007).

The objective of this study was to evaluate effects of the multi-year cereal monoculture and various tillage systems on the yield and weed infestation of winter durum wheat.

\section{Materials and Methods}

\section{Experiment Description}

An experiment with cropping systems and tillage systems was conducted in the years 1988-2018 at the Experimental Station Uhrusk belonging to the University of Life Sciences in Lublin (south-eastern Poland, 51 $1^{\circ} 18^{\prime} 12^{\prime \prime} \mathrm{N}, 23^{\circ} 36^{\prime} 48^{\prime \prime} \mathrm{E}$ ). The following cereals were grown in crop rotation and monoculture: winter triticale in the years 1988-2004, spring wheat in the years 2005-2012, as well as winter and spring wheat and durum wheat in the years 2012-2018. Results presented in this manuscript were collected in 2018.

\section{Soil and Climatic Conditions}

The soil the experiment was established on was Rendzic Phaeozem (IUSS Working Group WRB 2015). It contained $24 \%$ of the silty fraction and $13.3 \%$ of the dust fraction, and was characterized by alkaline $\mathrm{pH}\left(\mathrm{pH}_{\mathrm{KCL}}=7.4\right.$, determined in $1 \mathrm{~mol} \mathrm{KCL} \mathrm{dm}{ }^{-3}$ with the potentiometric method). It had medium contents of available phosphorus- $140 \mathrm{mg} \mathrm{P} \mathrm{kg}^{-1}$ d.m. (determined with the Egner-Riehm's method) and potassium-232 $\mathrm{mg} \mathrm{K} \mathrm{kg}^{-1} \mathrm{~d}$.m. (determined with the Egner-Riehm's method), and a moderate content of magnesium-61 $\mathrm{mg} \mathrm{mg} \mathrm{kg}^{-1} \mathrm{~d} . \mathrm{m}$. (determined with the Schachtschabels method). Organic carbon content in the soil reached $8.20 \mathrm{~g} \mathrm{~kg}^{-1}$ d.m. (determined with the Tiurin's method), and that of total nitrogen reached $0.90 \mathrm{~g} \mathrm{~N} \mathrm{~kg}^{-1}$ d.m. (assayed with the Kjeldahl's method).

The study area is characterized by a moderately long growing season spanning for 210 days on average (i.e. number of days with an average daily temperature above $+5^{\circ} \mathrm{C}$ ). The number of days with temperatures below $0{ }^{\circ} \mathrm{C}$ accounts for 90 on average. January is the coldest month throughout the year with an average air temperature of $-5^{\circ} \mathrm{C}$, whereas July is the warmest month with an average temperature of $+18.5^{\circ} \mathrm{C}$. The variability of thermal conditions in the studied years was presented in Fig. 1. In the 30-year period, the highest average annual air temperatures were recorded in $2015\left(10.1{ }^{\circ} \mathrm{C}\right)$, and the lowest ones in $1996\left(6.3{ }^{\circ} \mathrm{C}\right)$. High variability was also observed in the distribution of atmospheric precipitation (Fig. 2). In the cold half-year (since November till April), average atmospheric precipitation reached 200-225 mm, whereas in the warm half-year (since May till October) it reached $350-400 \mathrm{~mm}$. Throughout the study years, the highest sums of precipitation were recorded in 2009 (822 mm), and the lowest ones in 2018 (413 mm).
Fig. 1 Average annual air temperatures $\left({ }^{\circ} \mathrm{C}\right)$ in study years

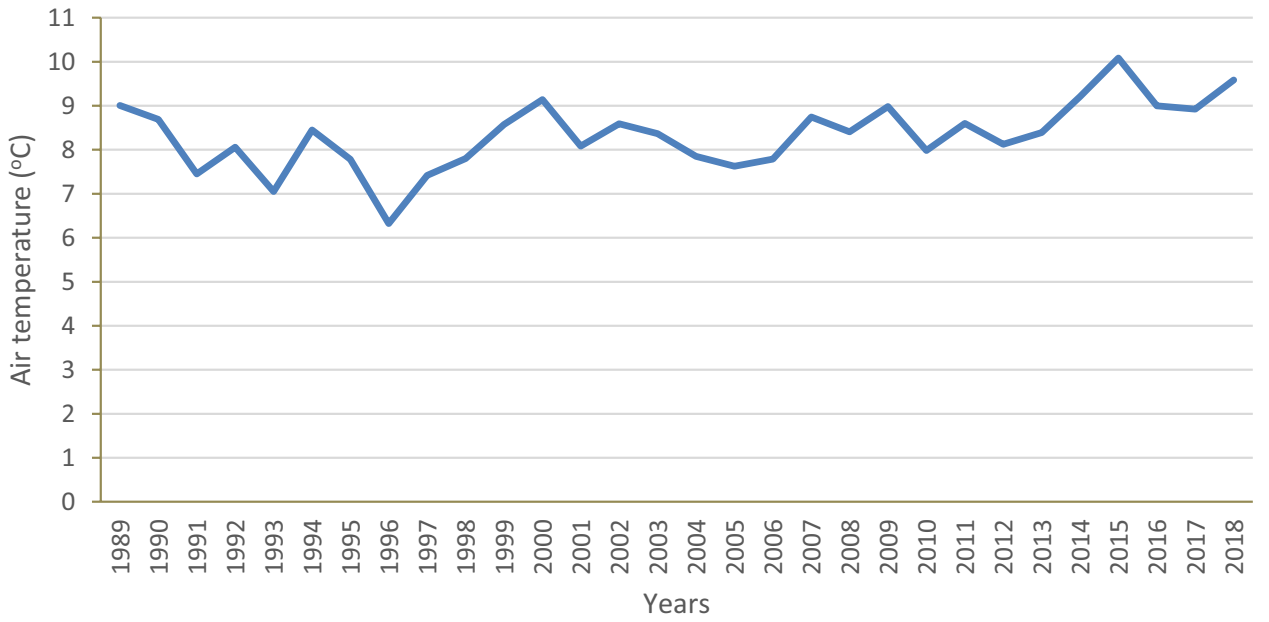


Fig. 2 Average sums of precipitation $(\mathrm{mm})$ in study years

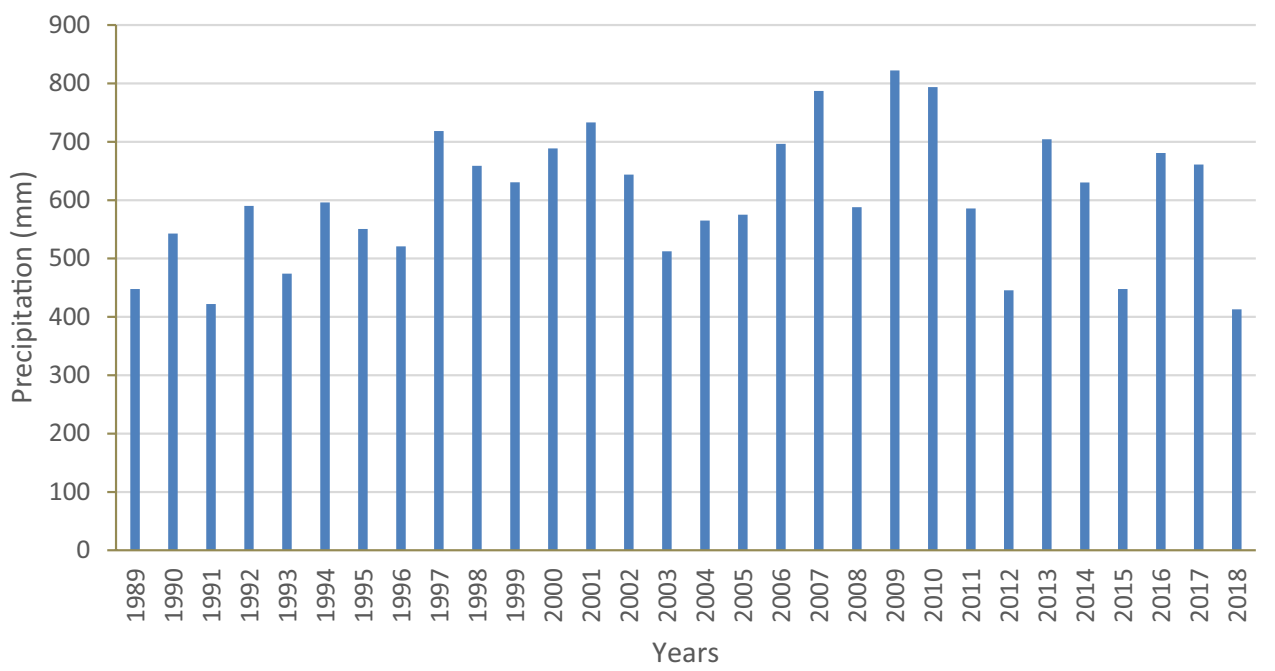

\section{Experimental Design and Statistical Analysis}

The experiment was established with the method of randomized sub-blocks $(6 \times 25 \mathrm{~m})$, in 3 replications. The first order experimental factors included: I. CS—cropping systems: (1) CR—crop rotation: pea-winter wheat-winter durum wheat; (2) $\mathrm{CM}-$ crop monoculture—durum wheat; and II. TS—-tillage systems: (1) CT-conventional tillage; (2) RT-reduced tillage; (3) and NT-no-tillage. In CT, shallow ploughing at a depth of $10-12 \mathrm{~cm}$ was performed immediately after the harvest of the previous crop and then pre-sowing ploughing at a depth of $20-25 \mathrm{~cm}$ in the middle of September. In turn, a cultivator $(10-15 \mathrm{~cm})$ and a tillage set consisting of a cultivator, a string roller and a harrow $(10-12 \mathrm{~cm})$ in the RT system, whereas glyphosate and a tillage set in the NT system.

Durum wheat of Spiradur cultivar was sown at the end of September in the amount of 475 seeds $\mathrm{m}^{-2}$. Nitrogen $\left(20 \mathrm{~kg} \mathrm{~N} \mathrm{ha}^{-1}\right)$, phosphorus $\left(28 \mathrm{~kg} \mathrm{P} \mathrm{ha}^{-1}\right)$, and potassium $\left(75 \mathrm{~kg} \mathrm{~K} \mathrm{ha}^{-1}\right)$ fertilizers were applied before the pre-sowing ploughing. Fertilization was calculated according soil chemical analysis. In the springtime, nitrogen was used in the following doses: (1) $70 \mathrm{~kg} \mathrm{ha}^{-1}$ at the tillering stage (22-23 in BBCH scale) (BBCH Working Group 2001); (2) $30 \mathrm{~kg} \mathrm{ha}^{-1}$ at the shooting stage (32-33 BBCH); and (3) $20 \mathrm{~kg} \mathrm{ha}^{-1}$ at the onset of ear formation stage $(52-53 \mathrm{BBCH})$. Wheat was harvested with a plot harvester at the beginning of August, at $13 \%$ moisture content of the grain. Wheat crops were protected against fungal diseases at the following developmental stages: (1) stage 31-32 BBCH (a.s. flusilazole + carbendazim); and (2) stage 43-44 BBCH (a.s. propiconazole + fenpropidin). Weed control was performed in the first term of weed infestation assessment, i.e. at stage $23-24 \mathrm{BBCH}$, with a herbicide containing MCPA + mecoprop + dicamba.

Determinations were conducted for: grain yield, spike number per $\mathrm{m}^{2}$, grain weight per spike, 1000 grain weight,

number of weeds at stages $22-23 \mathrm{BBCH}$ and $83-85 \mathrm{BBCH}$, air-dry weight of weeds at stage $83-85 \mathrm{BBCH}$, and weed species composition at both developmental stages of wheat. The number and species composition of weeds was determined twice on the area of $\mathrm{m}^{2}$ of each plot, using a frame $(1.0 \mathrm{~m} \times 0.5 \mathrm{~m})$. Determination of the air-dry weight of weeds consisted in their manual picking from the marked areas and placing them in a ventilated room until their constant weight has been achieved.

Results obtained were scrutinized with the method of the analysis of variance (ANOVA), whereas significance of differences between mean values was evaluated using Tukey's HSD test, $\mathrm{P}<0.05$.

\section{Results}

\section{Grain Yield and Its Components}

Wheat grain yield was significantly lower (by $63.4 \%$ ) in the 30 -year cereal monoculture $(\mathrm{CM})$ than in the crop rotation

Table 1 Grain yield of winter durum wheat in $\mathrm{tha}^{-1}$

\begin{tabular}{|c|c|c|c|}
\hline \multirow{2}{*}{$\begin{array}{l}\text { Tillage } \\
\text { system } \\
\text { (TS) }\end{array}$} & \multicolumn{2}{|c|}{$\begin{array}{l}\text { Cropping } \\
\text { system (CS) }\end{array}$} & \multirow[t]{2}{*}{ Mean } \\
\hline & $\mathrm{CR}^{\mathrm{a}}$ & $\mathrm{CM}^{\mathrm{b}}$ & \\
\hline $\mathrm{CT}^{\mathrm{c}}$ & 5.64 & 1.94 & 3.79 \\
\hline $\mathrm{RT}^{\mathrm{d}}$ & 3.83 & 1.13 & 2.48 \\
\hline $\mathrm{NT}^{\mathrm{e}}$ & 2.26 & 1.21 & 1.73 \\
\hline Mean & 3.91 & 1.43 & - \\
\hline \multicolumn{4}{|c|}{$\begin{array}{l}\mathrm{HSD}_{0.05} \text { for } \mathrm{CS}=0.14 ; \\
\mathrm{TS}=0.09 ; \mathrm{CS} \times \mathrm{TS}=0.22\end{array}$} \\
\hline \multicolumn{4}{|c|}{$\begin{array}{l}{ }^{\mathrm{a}} C R \text { crop rotation, }{ }^{\mathrm{b}} C M \text { cereal } \\
\text { monoculture, }{ }^{\mathrm{c}} C T \text { conventional } \\
\text { tillage, }{ }^{\mathrm{d}} R T \text { reduced tillage, }{ }^{\mathrm{e}} N T \\
\text { no-tillage }\end{array}$} \\
\hline
\end{tabular}


(CR) (Table 1). Lower yields were also determined in NT than in RT and CT systems (by $30.2 \%$ and $54.3 \%$, respectively) as well as in RT than in CT system (by $34.5 \%$ ). Significant $\mathrm{CS} \times \mathrm{TS}$ interactions were observed in all plots, however the lowest wheat grain yield was determined in CM with RT (1.13 $\left.\mathrm{t} \mathrm{ha}^{-1}\right)$, and the highest one in CR with CT $\left(5.64 \mathrm{t} \mathrm{ha}^{-1}\right)$. The lower grain yields in CM were due to the lower spike number per $\mathrm{m}^{2}$ (by $43 \%$ ), grain weight per spike (by 34.4\%), and 1000 grain weight (by 29.8\%), compared to CR (Table 2). Also the lower yields determined in NT resulted from a lower spike number per $\mathrm{m}^{2}$ than in RT and CT systems (by $16.7 \%$ and $34.5 \%$, respectively), a lower grain weight per spike than in RT and CT systems (by $8.0 \%$ and $26.6 \%$, respectively), as well as by lower 1000 grain weight compared to RT and CT systems (by $9.3 \%$ and $28.1 \%$, respectively). Components of the variance analysis indicated that grain yield, spike number per $\mathrm{m}^{2}$, grain weight per spike, and 1000 grain weight were affected to a greater extent by CS than TS and effects of CS $\times$ TS interaction (Table 3).

Table 2 Components of winter durum wheat yield

\begin{tabular}{|c|c|c|c|}
\hline \multirow{2}{*}{$\begin{array}{l}\text { Tillage } \\
\text { system } \\
\text { (TS) }\end{array}$} & \multicolumn{2}{|c|}{$\begin{array}{l}\text { Cropping } \\
\text { system (CS) }\end{array}$} & \multirow[t]{2}{*}{ Mean } \\
\hline & $\overline{\mathrm{CR}^{\mathrm{a}}}$ & $\mathrm{CM}^{\mathrm{b}}$ & \\
\hline \multicolumn{4}{|c|}{ Spike number per $\mathrm{m}^{2}$} \\
\hline $\mathrm{CT}^{\mathrm{c}}$ & 538.3 & 233.0 & 385.7 \\
\hline $\mathrm{RT}^{\mathrm{d}}$ & 407.0 & 199.7 & 303.3 \\
\hline $\mathrm{NT}^{\mathrm{e}}$ & 254.0 & 251.0 & 252.5 \\
\hline Mean & 399.8 & 227.9 & - \\
\hline \multicolumn{4}{|c|}{$\begin{array}{l}\mathrm{HSD}_{0.05} \text { for } \mathrm{CS}=7.2 ; \\
\mathrm{TS}=13.2 ; \mathrm{CS} \times \mathrm{TS}=33.3\end{array}$} \\
\hline \multicolumn{4}{|c|}{ Grain weight per spike (g) } \\
\hline $\mathrm{CT}$ & 1.05 & 0.83 & 0.94 \\
\hline RT & 0.94 & 0.56 & 0.75 \\
\hline NT & 0.89 & 0.48 & 0.69 \\
\hline Mean & 0.96 & 0.63 & - \\
\hline \multicolumn{4}{|c|}{$\begin{array}{l}\mathrm{HSD}_{0.05} \text { for } \mathrm{CS}=0.02 \\
\mathrm{TS}=0.04 ; \mathrm{CS} \times \mathrm{TS}=0.09\end{array}$} \\
\hline \multicolumn{4}{|c|}{1000 grain weight $(\mathrm{g})$} \\
\hline $\mathrm{CT}$ & 46.1 & 38.0 & 42.0 \\
\hline RT & 40.9 & 25.6 & 33.3 \\
\hline NT & 36.9 & 23.5 & 30.2 \\
\hline Mean & 41.3 & 29.0 & - \\
\hline \multicolumn{4}{|c|}{$\begin{array}{l}\mathrm{HSD}_{0.05} \text { for } \mathrm{CS}=0.7 ; \\
\mathrm{TS}=1.3 ; \mathrm{CS} \times \mathrm{TS}=3.2\end{array}$} \\
\hline
\end{tabular}

Table 3 Variance analysis for winter durum wheat yield and its components

\begin{tabular}{lllll}
\hline Specification & Value & $\mathrm{CS}^{\mathrm{a}}$ & $\mathrm{TS}^{\mathrm{b}}$ & $\mathrm{CS} \times \mathrm{TS}$ \\
\hline Grain yield & $F$ & 1434.6 & 335.9 & 137.9 \\
& $P$ & $* *$ & $* *$ & $* *$ \\
Spike number per $\mathrm{m}^{2}$ & $F$ & 301.4 & 61.4 & 80.9 \\
& $P$ & $* *$ & $* *$ & $* *$ \\
Grain weight per spike & $F$ & 143.6 & 29.9 & 4.5 \\
& $P$ & $* *$ & $* *$ & $*$ \\
1000 grain weight & $F$ & 170.0 & 56.6 & 5.2 \\
& $P$ & $* *$ & $* *$ & $*$ \\
\hline
\end{tabular}

${ }^{\mathrm{a}} \mathrm{CS}$ cropping system, ${ }^{\mathrm{b}} T S$ tillage system, $* P<0.05, * * P<0.01$

\section{Number and Air-Dry Weight of Weeds}

At the tillering stage of wheat (22-23 BBCH), weed number per $\mathrm{m}^{2}$ in the monoculture (CM) was higher by $36.3 \%$ than in the crop rotation (CR) (Table 4). A higher number of weeds per $\mathrm{m}^{2}$ was also determined in RT than in NT and CT systems (by $39.4 \%$ and $71.1 \%$, respectively). A significantly higher weed number per $\mathrm{m}^{2}$ was also detected in NT than in CT system (by 51.7\%). The weed number was higher in CM than in CR (by $18.1 \%$ ) also at the waxy maturity stage of wheat (83-85 BBCH)-Table 5. At this developmental stage of wheat, a higher number of weeds per $\mathrm{m}^{2}$ was also observed in RT than in NT (by 21.4\%) and CT (by 58.1\%). Similar observations were made for the air-dry weight of weeds, which was higher in CM than in CR (by 27.7\%), and also in NT and RT than in CT system (by 47.4-51.2\%). Components of the variance analysis indicated that at the 22-23 BBCH and 83-85 BBCH developmental stages, both the weed number and the air-dry weight of weeds were influenced to a greater extent by TS than by CS (Table 6).
Table 4 Number of weeds per $\mathrm{m}^{2}$ in the stand of winter durum wheat at the tillering stage (22-23 BBCH)

\begin{tabular}{llll}
\hline $\begin{array}{l}\text { Tillage } \\
\text { system } \\
(\mathrm{TS})\end{array}$ & \multicolumn{2}{l}{$\begin{array}{l}\text { Cropping } \\
\text { system }(\mathrm{CS})\end{array}$} & Mean \\
\cline { 2 - 3 } $\mathrm{CR}^{\mathrm{a}}$ & $\mathrm{CM}^{\mathrm{b}}$ & \\
\hline $\mathrm{CT}^{\mathrm{c}}$ & 15.9 & 24.0 & 19.9 \\
$\mathrm{RT}^{\mathrm{d}}$ & 60.0 & 77.5 & 68.8 \\
$\mathrm{NT}^{\mathrm{e}}$ & 25.2 & 57.2 & 41.2 \\
$\mathrm{Mean}$ & 33.7 & 52.9 & - \\
$\mathrm{HSD}_{0.05}$ for $\mathrm{CS}=8.9 ;$ \\
$\mathrm{TS}^{2} 13.4 ; \mathrm{CS} \times \mathrm{TS}=\mathrm{ns}$ \\
\hline${ }^{\mathrm{a} C R}$ crop rotation, ${ }^{\mathrm{b}} C M$ cereal \\
monoculture, ${ }^{\mathrm{c}} C T$ conventional \\
tillage, ${ }^{\mathrm{d}} R T$ reduced tillage, ${ }^{\mathrm{e}} N T$ \\
no-tillage, $n s$ not significant
\end{tabular}


Table 5 Number and air-dry weight of weeds in $\mathrm{g} \mathrm{m}^{-2}$ in the stand of winter durum wheat at the stage of waxy maturity (83-85 BBCH)

\begin{tabular}{|c|c|c|c|}
\hline \multirow{2}{*}{$\begin{array}{l}\text { Tillage } \\
\text { system } \\
\text { (TS) }\end{array}$} & \multicolumn{2}{|c|}{$\begin{array}{l}\text { Cropping } \\
\text { system (CS) }\end{array}$} & \multirow[t]{2}{*}{ Mean } \\
\hline & $\mathrm{CR}^{\mathrm{a}}$ & $\mathrm{CM}^{\mathrm{b}}$ & \\
\hline \multicolumn{4}{|c|}{ Number of weeds per $\mathrm{m}^{2}$} \\
\hline $\mathrm{CT}^{\mathrm{c}}$ & 24.3 & 38.1 & 31.2 \\
\hline $\mathrm{RT}^{\mathrm{d}}$ & 67.8 & 80.9 & 74.4 \\
\hline $\mathrm{NT}^{\mathrm{e}}$ & 55.6 & 61.3 & 58.5 \\
\hline Mean & 49.2 & 60.1 & - \\
\hline \multicolumn{4}{|c|}{$\begin{array}{l}\mathrm{HSD}_{0.05} \text { for } \mathrm{CS}=8.5 ; \\
\mathrm{TS}=12.7 ; \mathrm{CS} \times \mathrm{TS}=\mathrm{ns}\end{array}$} \\
\hline \multicolumn{4}{|c|}{ Air-dry weight $\mathrm{g} \mathrm{m}^{-2}$} \\
\hline $\mathrm{CT}$ & 26.0 & 50.1 & 38.1 \\
\hline RT & 64.5 & 80.2 & 72.4 \\
\hline NT & 66.5 & 86.4 & 76.5 \\
\hline Mean & 52.3 & 72.3 & - \\
\hline \multicolumn{4}{|c|}{$\begin{array}{l}\mathrm{HSD}_{0.05} \text { for } \mathrm{CS}=10.1 ; \\
\mathrm{TS}=15.1 ; \mathrm{CS} \times \mathrm{TS}=\mathrm{ns}\end{array}$} \\
\hline
\end{tabular}

\section{Species Composition of Weeds}

The number of species and species composition depended on both cropping systems (CS) and tillage systems (TS)Fig. 3. The number of weed species identified at the 22-23 $\mathrm{BBCH}$ stage of wheat development in the cereal monoculture (CM) reached 10 in RT, 7 in CT, and 7 in NT. In the crop rotation (CR), 7 species were found in NT plots, whereas 5 species in both CT and RT plots. In turn, the number of weed species identified at the $83-85 \mathrm{BBCH}$ stage of wheat development in the monoculture (CM) reached 15 in RT plots, 11 in CT plots, and 8 in NT plots. In the CR system, weed community on RT plots consisted of 17 species, on CT plots — of 14 species, and on NT plots — of 10 species.

At the 22-23 BBCH stage, the prevailing weed species identified in wheat grown in the monoculture (CM) included: in CT-Anthemis arvensis, Stellaria media, and Viola arvensis; in RT-Apera spica-venti, Anthemis arvensis, and Stellaria media; and in NT-Apera spica-venti, Lamium amplexicaule, and Veronica persica (Fig. 4). The prevailing species identified in the crop rotation system (CR) included: in CT-Veronica persica and Lamium amplexicaule; in RT and NT-Veronica persica and Galium aparine (Fig. 5). In turn, the prevailing species determined at the 83-85 BBCH developmental stage of wheat sown in the monoculture (CM) included: in CT-Apera spica-venti, Avena fatua, and Fallopia convolvulus; in RT-Apera spicaventi, Avena fatua, and Papaver rhoeas; and in NT-Apera spica-venti, Avena fatua, and Consolida regalis (Fig. 6). Finally, the prevailing weed species noted in crop rotation (CR) included: in CT-Papaver rhoeas, Avena fatua, and Apera spica-venti; in RT-Apera spica-venti, Papaver rhoeas, and Galium aparine, and in NT-Apera spica-venti, Papaver rhoeas, and Consolida regalis (Fig. 7).

${ }^{\mathrm{a}} \mathrm{CS}$ cropping system, ${ }^{\mathrm{b}} T S$ tillage system, ${ }^{*} P<0.05$, $* * P<0.01, n s$ not significant

Fig. 3 Number of weed species per $\mathrm{m}^{2}$ of winter durum wheat in crop rotation $(\mathrm{CR})$ and cereal monoculture $(\mathrm{CM})$, at the stage of tillering $(22-23 \mathrm{BBCH})$ and waxy maturity $(83-85 \mathrm{BBCH})$; $C T$ conventional tillage, $R T$ reduced tillage, $N T$ no-tillage

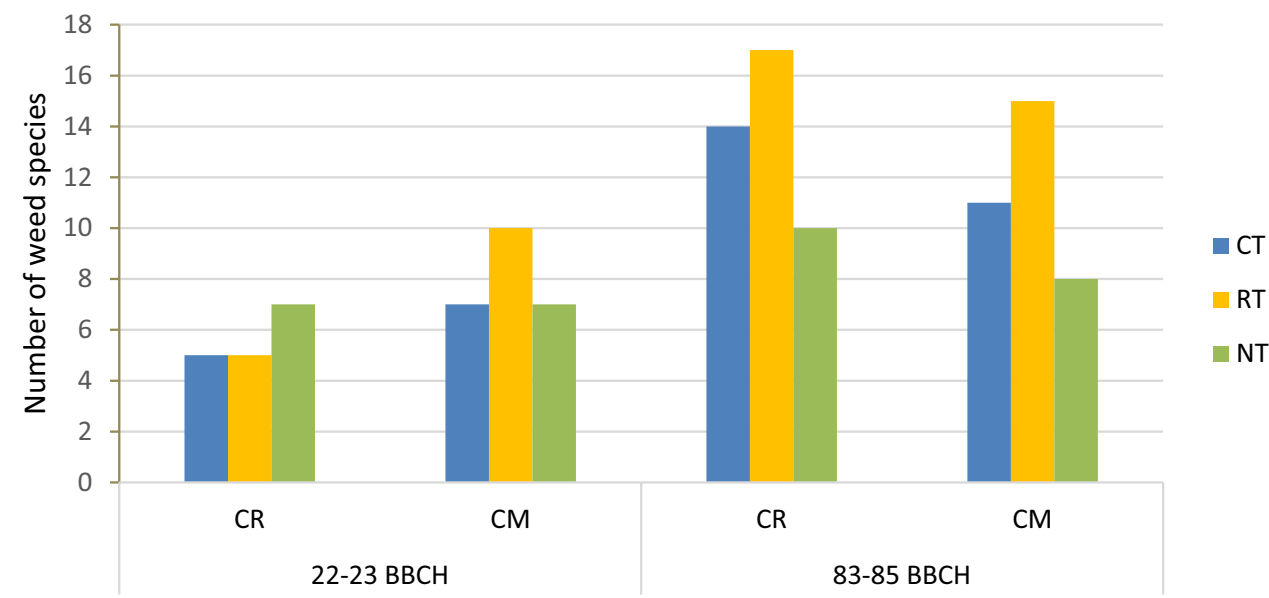


Fig. 4 Species composition of weeds in the stand of winter durum wheat sown in cereal monoculture $(\mathrm{CM})$, at the tillering stage (22-23 BBCH); $C T$ conventional tillage, $R T$ reduced tillage, $N T$ no-tillage
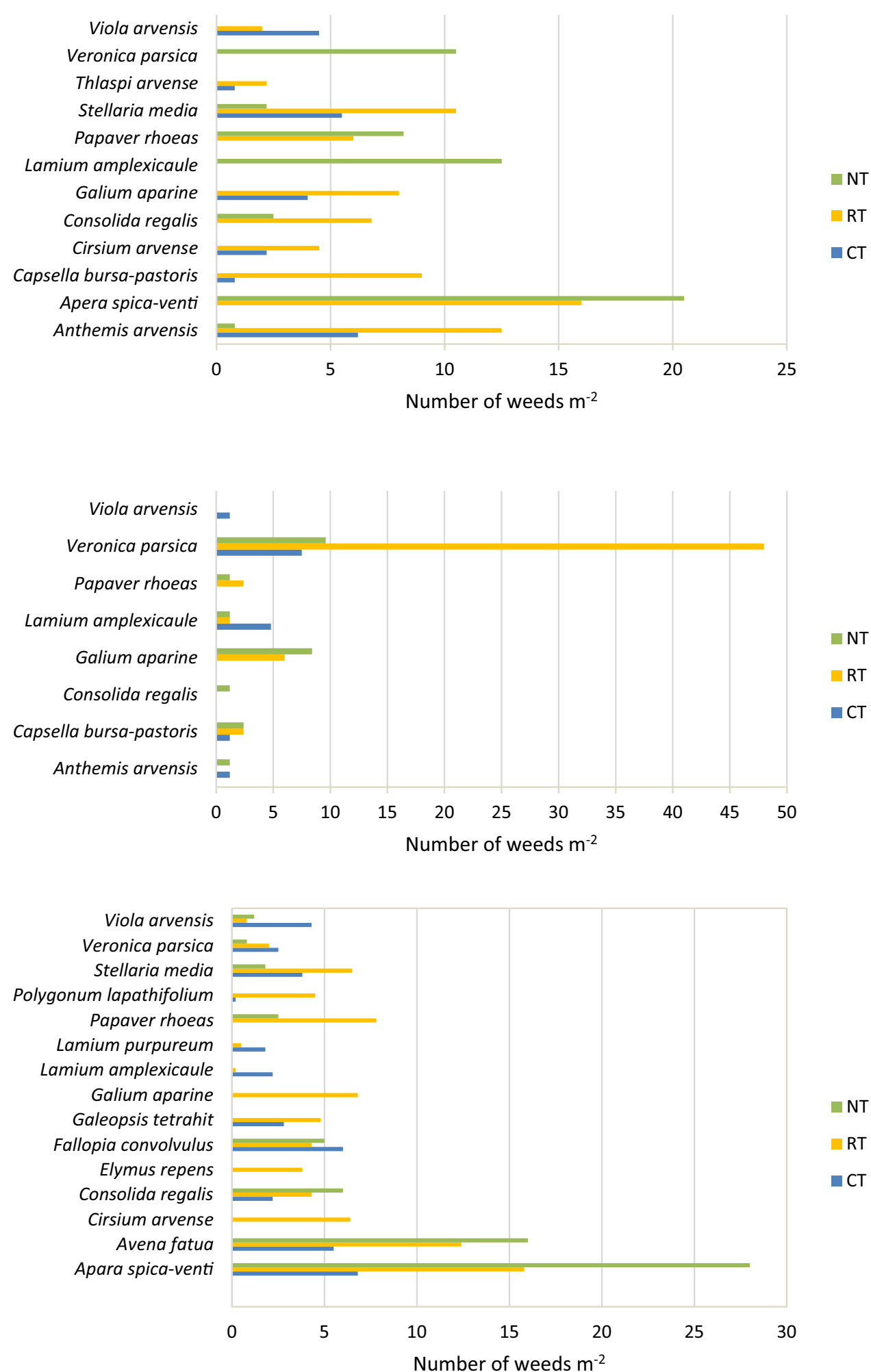

Fig. 5 Species composition of weeds in the stand of winter durum wheat sown in crop rotation (CR), at the tillering stage (22-23 BBCH); $C T$ conventional tillage, $R T$ reduced tillage, $N T$ no-tillage
Fig. 6 Species composition of weeds in the stand of winter durum wheat sown in cereal monoculture (CM), at the stage of waxy maturity (83-85 $\mathrm{BBCH}) ; C T$ conventional tillage, $R T$ reduced tillage, $N T$ no-tillage

\section{Discussion}

Cultivation of cereals in the monoculture contributes to decreased grain yield and quality. The extent of this decrease varies and depends on habitat factors, agrotechnical measures used, cultivated species and even cultivar. In a research conducted by Ventrella et al. (2016), grain yield, protein content of the grain, and weight of a hectoliter of winter durum wheat did not decrease significantly in the multi-year 
Fig. 7 Species composition of weeds in the stand of winter durum wheat sown in crop rotation (CR), at the stage of waxy maturity (83-85 BBCH); $C T$ conventional tillage, $R T$ reduced tillage, $N T$ no-tillage

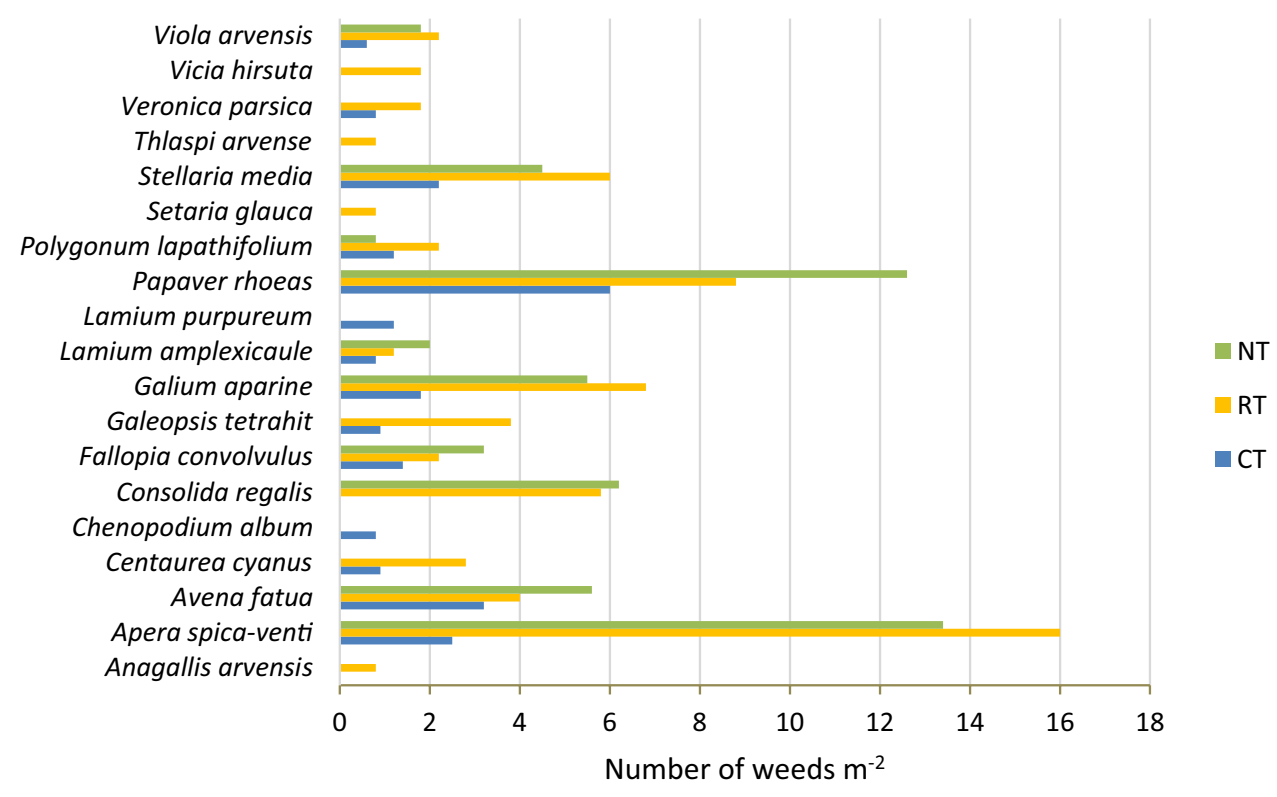

monoculture compared to the crop rotation system. In this study, grain yield of winter durum wheat grown in the 30-year cereal monoculture (CM) was significantly lower than in the crop rotation (CR) $\left(1.43 \mathrm{t} \mathrm{ha}^{-1}\right.$ vs. $\left.3.91 \mathrm{t} \mathrm{ha}^{-1}\right)$. This was due to a lower spike number per $\mathrm{m}^{2}$, grain weight per spike, and 1000 grain weight in CM than in CR. Most often, these adverse changes result from increased weed infestation or from an increased plant infection by fungal pathogens (Woźniak and Soroka 2015; Tillmann et al. 2017; Calzarano et al. 2018). Especially high risk is posed by takeall diseases, because they infect stands of winter cereals already in the autumn when they decrease plant number as well as in the spring and early summer when they reduce numbers of shoots and spikes (Hernández-Restrepo et al. 2016). The infected plants produce small and poorly-filled grain characterized by a low mass, poor uniformity, and poor quality. In this study, the number of weeds per $\mathrm{m}^{2}$ was higher in the monoculture $(\mathrm{CM})$ than in the crop rotation (CR) on both terms of weed infestation assessment. Also, the air-dry weight of weeds were higher in CM than in CR at the stage of waxy maturity of wheat. Components of the variance analysis demonstrated that, at both developmental stages of wheat, the weed number and weed biomass were affected to a greater extent by the tillage system than by the cropping system. Similar observations were made by Tuesca et al. (2001), Gruber et al. (2012), and Woźniak (2018). In this study, the highest number of weeds occurred in the monoculture (CM) on RT and NT plots, compared to the crop rotation (CR) with CT system. This was reflected in grain yields which were lower at these plots than in CR. As reported by Marque et al. (2004), most of the cultivars of durum wheat are the spring ones, while their winter forms are superior to them due to their naturally higher yielding potential. These observations indicate that the winter form may be more sensitive than the spring one to unfavorable agrotechnical conditions, including cultivation in the monoculture and no-tillage system. This was confirmed in a study by Woźniak and Stępniowska (2017), in which the spring form of durum wheat sown in similar habitat conditions and subjected to similar agrotechnical measures produced a higher yield in the herbicide system than in the reduced and conventional tillage systems.

Cereal crops are accompanied by communities of weeds which in most cases belong to the syntaxonomic class Stellarietea mediae with a typical assembly Apero spica-ventiPapaveretum rhoeadis (Woźniak and Soroka 2015). Species representing this syntaxonomic group prevailed also in this study, however Apera spica-venti (28 plants per $\mathrm{m}^{2}$ in NT) and Avena fatua (16 plants per $\mathrm{m}^{2}$ in NT) prevailed in the cereal monoculture, whereas Apera spica-venti (16 plants per $\mathrm{m}^{2}$ in RT) and Papaver rhoeas (12.6 plants per $\mathrm{m}^{2}$ in $\mathrm{NT})$ in the crop rotation (CR) system.

\section{Conclusions}

Cultivation of winter durum wheat in the multi-year cereal monoculture (CM) significantly decreased grain yield compared to the crop rotation (CR) system. The lower grain yields were also determined in NT than in RT and CT systems. This decrease in grain yield was due to a lower spike number per $\mathrm{m}^{2}$, lower grain weight per spike, and lower 1000 grain weight. Grain yield and its components were affected to a greater extent by the cropping systems (CS) than by the tillage systems (TS). A higher number of weeds per $\mathrm{m}^{2}$ and a 
higher air-dry weight of weeds were determined in CM than in CR as well as in RT compared to CT and NT systems. Short-term weed species prevailed in the wheat stand, except for Cirsium arvense and Elymus repens which occurred in the cereal monoculture (CM). In addition, Apera spica-venti and Avena fatua prevailed in the CM system, whereas Apera spica-venti and Papaver rhoeas in the CR system.

Open Access This article is distributed under the terms of the Creative Commons Attribution 4.0 International License (http://creativeco mmons.org/licenses/by/4.0/), which permits unrestricted use, distribution, and reproduction in any medium, provided you give appropriate credit to the original author(s) and the source, provide a link to the Creative Commons license, and indicate if changes were made.

\section{References}

Balota, E. L., Kanashiro, M., Filho, A. C., Andrade, D. S., \& Dick, R. P. (2004). Soil enzyme activities under long-term tillage and crop rotation systems in subtropical agroecosystems. Brazilian Journal of Microbiology, 35, 300-306.

BBCH Working Group. (2001). Growth stages of mono-and dicotyledonous plants. In U. Meier (Ed.), Federal biological research centre for agriculture and forestry (2nd ed.). Hoboken: Blackwell.

Calzarano, F., Stagnari, F., D’Egidio, S., Pagnani, G., Galieni, A., Di Marco, S., et al. (2018). Durum wheat quality, yield and sanitary status under conservation agriculture. Agriculture, 8, 140.

Chauhan, B. S., Gill, G. S., \& Preston, C. (2006). Tillage system effects on weed ecology, herbicide activity and persistence: A review. Australian Journal of Experimental Agriculture, 46, 1557-1570.

Chauhan, B. S., Singh, R. G., \& Mahajan, G. (2012). Ecology and management of weeds under conservation agriculture: A review. Crop Protection, 38, 57-65.

De Vita, P., Di Paolo, E., Fecondo, G., Di Fonzo, N., \& Pisante, M. (2007). No-tillage and conventional tillage effects on durum wheat yield, grain quality, and soil moisture content in Southern Italy. Soil and Tillage Research, 92, 69-78.

Gruber, S., Pekrun, C., Möhring, J., \& Claupein, W. (2012). Long-term yield and weed response to conservation and stubble tillage in SW Germany. Soil and Tillage Research, 121, 49-56.

Hernández Plaza, E., Navarrete, L., \& González-Andújar, J. L. (2015). Intensity of soil disturbance shapes response trait diversity of weed communities: The long-term effects of different tillage systems. Agriculture, Ecosystems \& Environment, 207, 101-108.

Hernández-Restrepo, M., Groenewald, J. Z., Elliott, M. L., Canning, G., McMillan, V. E., \& Crous, P. W. (2016). Take-all or nothing. Studies in Mycology, 83, 19-48.

IUSS Working Group WRB (2015). World Reference Base for Soil Resources 2014, update 2015. International soil classification system for naming soils and creating legends for soil maps. World Soil Resources Reports No. 106. FAO, Rome.

Koning, L. A., de Mol, F., \& Gerowitt, B. (2019). Effects of management by glyphosate or tillage on the weed vegetation in a field experiment. Soil and Tillage Research, 186, 79-86.

Lahmar, R. (2010). Adoption of conservation agriculture in Europe lesson of the KASSA project. Land Use Policy, 27, 4-10.

López-Bellido, L., Fuentes, M., Castillo, J. E., López-Garrido, F. J., \& Fernández, E. J. (1996). Long-term tillage, crop rotation, and nitrogen fertilizer effects on wheat yield under rainfed Mediterranean conditions. Agronomy Journal, 88, 783-791.
Maillard, É., Angers, D. A., Chantigny, M., Lafond, J., Pageau, D., Rochette, P., et al. (2016). Greater accumulation of soil organic carbon after liquid dairy manure application under cereal-forage rotation than cereal monoculture. Agriculture, Ecosystems \& Environment, 233, 171-178.

Marque, V., Fritz, A. K., Martin, T. J., \& Paulsen, G. M. (2004). Agronomic and quality attributes of winter durum wheat in the Central Great Plains. Crop Science, 44, 878-883.

Montemurro, F. (2009). Different nitrogen fertilization sources, soil tillage, and crop rotations in winter wheat: Effect on yield, quality, and nitrogen utilization. Journal of Plant Nutrition, 32, 1-18.

Montemurro, F., \& Maiorana, M. (2015). Agronomic practices at low environmental impact for durum wheat in mediterranean conditions. Journal of Plant Nutrition, 38, 624-638.

Moyer, J. R., Roman, E. S., Lindwall, C. W., \& Blackshaw, R. E. (1994). Weed management in conservation tillage systems for wheat production in North and South America. Crop Protection, 13, 243-259.

Pardo, G., Cirujeda, A., Aibar, J., Cavero, J., \& Zaragoza, C. (2008). Weed harrowing in winter cereals under semi-arid conditions. Spanish Journal of Agricultural Research, 6, 661-670.

Peigné, J., Ball, B. C., Roger-Estrade, J., \& David, C. (2007). Is conservation tillage suitable for organic farming? Soil Use and Management, 23, 129-144.

Pekrun, C., \& Claupein, W. (2006). The implication of stubble tillage for weed population dynamics in organic farming. Weed Research, 46, 414-423.

Shahzad, M., Farooq, M., Jabran, K., \& Hussain, M. (2016). Impact of different crop rotations and tillage systems on weed infestation and productivity of bread wheat. Crop Protection, 89, 161-169.

Sieling, K., Stahl, C., Winkelmann, C., \& Christen, O. (2005). Growth and yield of winter wheat in the first 3 years of a monoculture under varying $\mathrm{N}$ fertilization in NW Germany. European Journal of Agronomy, 22, 71-84.

Tillmann, M., von Tiedemann, A., \& Winter, M. (2017). Crop rotation effects on incidence and diversity of Fusarium species colonizing stem bases and grains of winter wheat. Journal of Plant Diseases and Protection, 124, 121-130.

Tuesca, D., Puricelli, E., \& Papa, J. C. (2001). A long-term study of weed flora shifts in different tillage systems. Weed Research, 41, 369-382.

Ventrella, D., Stellacci, A. M., Castrignanò, A., Charfeddine, M., \& Castellini, M. (2016). Effects of crop residue management on winter durum wheat productivity in a long term experiment in Southern Italy. European Journal of Agronomy, 77, 188-198.

Woźniak, A. (2018). Effect of tillage system on the structure of weed infestation of winter wheat. Spanish Journal of Agricultural Research, 16, e1009.

Woźniak, A., \& Soroka, M. (2015). Structure of weed communities occurring in crop rotation and monoculture of cereals. International Journal of Plant Production, 9, 487-506.

Woźniak, A., \& Soroka, M. (2018). Effect of crop rotation and tillage system on the weed infestation and yield of spring wheat and on soil properties. Applied Ecology and Environmental Research, 16, 3087-3096.

Woźniak, A., \& Stępniowska, A. (2017). Yield and quality of durum wheat grain in different tillage systems. Journal of Elementology, $22,817-829$.

Zikeli, S., Gruber, S., Teufe, C. F., Hartung, K., \& Claupein, W. (2013). Effects of reduced tillage on crop yield, plant available nutrients and soil organic matter in a 12-year long-term trial under organic management. Sustainability, 5, 3876-3894. 